\title{
British Naval Power and its Influence on Indonesia, 1795-1942: An Historical Analysis
}

\author{
Peter Carey, ${ }^{1 *}$ Christopher Reinhart ${ }^{2}$ \\ ${ }^{1}$ Oxford University, United Kingdom \\ ${ }^{2}$ Department of History, Faculty of Humanities, Universitas Indonesia, Indonesia
}

DOI: https://doi.org/10.14710/jmsni.v5i1.9343

\begin{abstract}
In Indonesian history, Britain has never been considered a prominent player in the politics of the archipelago. From an Indonesian perspective, the British presence only lasted a brief five years (1811-1816) during short-lived interregnum regime led by Thomas Stamford Raffles (17811826). This began with the British seizure of Java from the Franco-Dutch administration of Marshal Daendels (1808-1811) and his successor, General Janssens (May-September 1811), and ended with the formal return of the colony to the Netherlands on 19 August 1816. However, as this article demonstrates, Britain has had a long-lasting and decisive influence on modern Indonesian history, dating from the time when the

Received:

November 9, 2020

Revised:

August 21, 2021

Accepted:

August 24, 2021

${ }^{*}$ Corresponding Author: peterbrcarey@hotmail.com archipelago entered the vortex of global conflict between Britain and Republican France in the 1790s. The presence of the British navy in Indonesian waters throughout the century and a half which followed Britain's involvement in the War of the First Coalition (1792-1797) dictated inter alia the foundation of new cities like Bandung which grew up along Daendels' celebrated postweg (military postroad), the development of modern Javanese cartography, and even the fate of the exiled Java War leader, Prince Diponegoro, in distant Sulawesi (1830-1855). As witnessed in the 20th century, the existence of the Dutch as colonial masters in the Indonesian Archipelago was critically dependent on the naval defence screen provided by the British. When the British lost their major battleships (Prince of Wales and Repulse) to Japanese attack off the east coast of Malaya on 10 December 1941 and Singapore fell on 15 February 1942, the fate of the Dutch East Indies was sealed. Today, the vital role played by the Royal Navy in guaranteeing the archipelago's security up to February 1942 has been replaced by that of the Honolulu-based US Seventh Fleet but the paradoxes of such protection have continued.
\end{abstract}

Keywords: British Navy; British in Indonesia; Intercolonial Relations; Indonesian Navy Defence.

\section{Introduction}

During the century and a half which stretched from the declaration of war on Britain by the French Republic on 1 February 1793 to the Battle of the Java Sea on 27 February 1942, British naval power was key to the defence of what would become-post-December 1818, called the Netherlands East Indies and-post-1945, called Indonesia. Operating initially from its bases in Madras (Chennai) and Penang (Georgetown) and subsequently from Singapore (post-1819)_later (1921-1941) a major base for the Royal Navy - the United Kingdom controlled naval access to Indonesia, thus providing a vital security screen for the vast Dutch colony. Post-war World, this screen would be provided by the immense power of the United States (US) Seventh Fleet which had replaced the Royal Navy following its naval victories over Japan at the battles of the Coral Sea (4-8 May 1942) and Midway (4-7 June 1942). The present article at the implications of this British security screen for political developments in the Dutch East Indies/Indonesia in the century and a half from the 1790s to the 
Dutch unconditional surrender to the Japanese on 8 March 1942 at Kalijati (Subang) following their lightning conquest of the archipelago.

From January 1793, when it entered the War of the First Coalition (1792-1797) against Republican France to the Battle of Waterloo on 18 June 1815, the United Kingdom was engaged in a global conflict which only ended with the final defeat of Napoleon. This was both a military and an ideological conflict akin to the Cold War (1947-1991), which split the post-war world into Communist and anti-Communist (Liberal Democratic) camps, or the anti-fascist struggle between the Allies and the totalitarian states (Germany, Italy, Japan) in World War II. If Britain and her allies had not prevailed militarily and ideologically during the Revolutionary and Napoleonic Wars, which in the view of the present authors were the first truly global conflicts of the modern era, the world (at least the European and Atlantic worlds) would have been very different. Time-hallowed hereditary and monarchical principles would have been overturned in favour of a republican political format and the British monarchy abolished along with the British aristocracy and pre-Revolutionary-ancien régime-landholding systems and inheritance based on primogeniture. These would have been replaced by universal property rights legislated in the Napoleonic Code (1804), thus doing away with privilege based on birth in favour of a Republican meritocracy. In international terms, France would have replaced Britain as the dominant power in Western Europe and the Atlantic with the recently established Republic of the United States becoming a French client state and almost certainly, like Quebec, francophone.

There were thus hugely important strategic and political issues at stake in this conflict for Britain. It was a conflict she had to win in order to preserve her position as the world's leading commercial power, the apogee of which occurred precisely in this half-century between 1780 and 1830 as British History, Chris Bayly, argued in his Imperial Meridian (1989) rather than later during the Victorian imperial era, 1837-1901, as the popular version of Britain's imperial history would have it.

How does the Netherlands East Indies fit into this? Surely these European and trans-Atlantic conflicts had little impact on distant Southeast Asia? Unfortunately, this was not the case. The successful French invasion of the Netherlands in the winter of 1794/1795, had ensured that Java and the eastern archipelago had become part of that wider global struggle. This was because the Dutch Republic_now rechristened the Batavian Republic (1795-1806) following the French military takeover-had become a client state of Revolutionary France. It was this French-controlled Republic which had assumed control of the assets of the now-bankrupt (1798) and defunct (1799) Dutch East India Company (Vereenigde Oostindische Compagnie, VOC), a takeover contested by the former Dutch Head of State (Stadhouder), Prince Willem V of Orange (r. 1751-1806). On 18 January 1795 as French troops closed in on his capital, The Hague, he had fled into exile in London, and, from the Palace in what is now the borough of Richmond-on-Thames, made available to him by the British monarch, George III (r. 1760-1820), he had issued the so-called 'Kew Letters' (30 January-8 February 1795) ordering the heads of Dutch trading posts and possessions east of the Cape of Good Hope to hand those posts over to the British rather than allow them to fall into French hands. In this way, Java and the Dutch possessions in the outer islands (Ambon, Seram, Makassar, Manado, Padang etc.) became involved in the ongoing global struggle between France and Britain.

British naval operations in Indonesian waters began in earnest in late 1795 and early 1796, when a fleet under the command of Commodore Peter Rainier (1741-1808), Commander-in-Chief of the East Indies Station (1794-1805), swept through Indonesia capturing most of the Dutch possessions outside Java. The highpoint of Rainier's naval operations against the VOC took place on 23 August 1800, when his squadron of just three frigates and one ship-of-the-line, HMS Centurion, a 50-gun Salisbury Class Fourth Rate battleship, entered the roads of Batavia, and captured five Dutch armed vessels and 22 merchantmen some of which were taken as a prize to Penang. Although all the Dutch possessions outside Java barring Ceylon (post-1972 Sri Lanka) and Cape Colony (South Africa) were returned to the Dutch at the Treaty of Amiens (27 March 1802), they were swiftly recaptured after general hostilities broke out again the following year (18 May 1803) (Figure 1). 


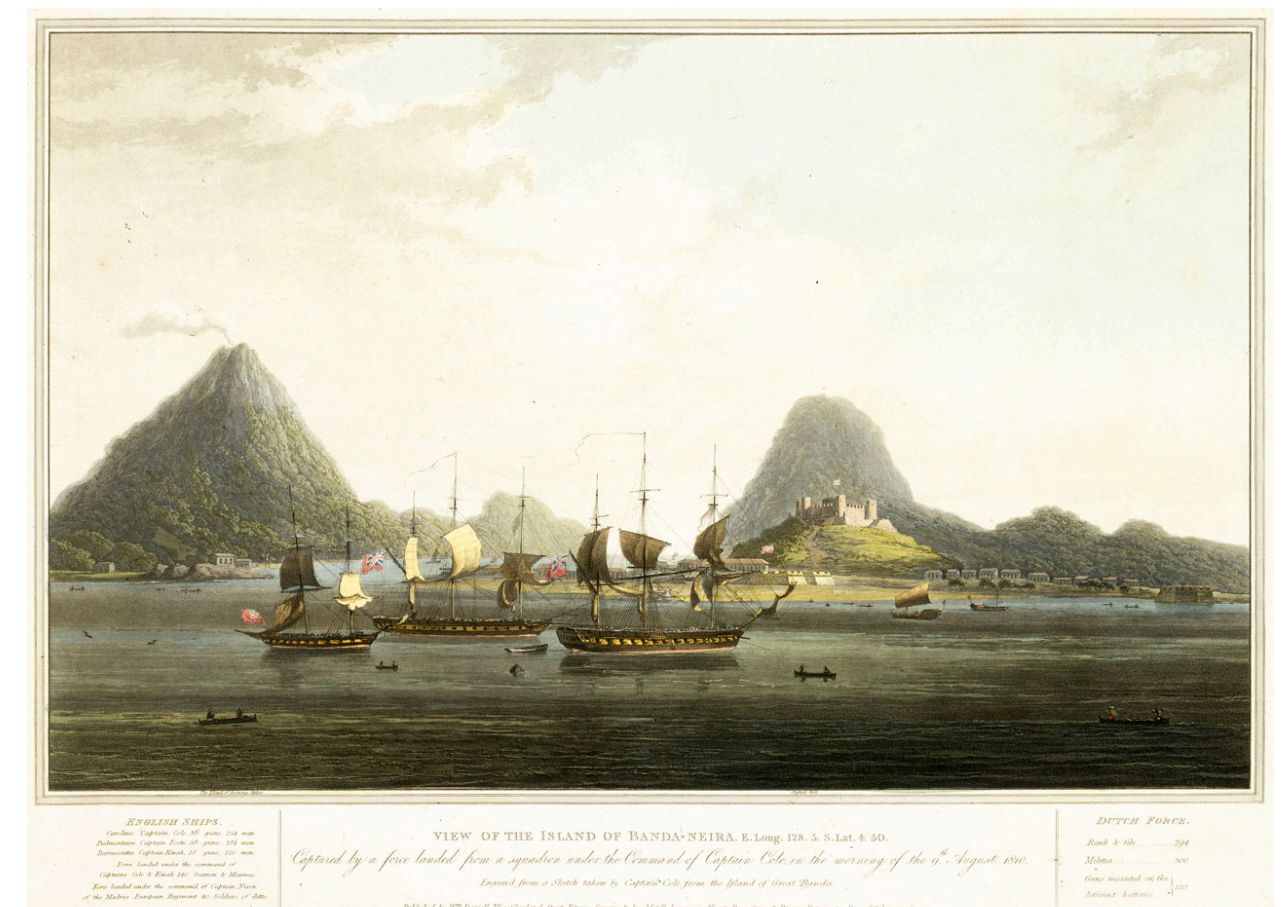

Figure 1. 'View of the Island of Banda Neira Captured by a force landed from a squadron under the command of Captain [Christopher] Cole on the morning of $9^{\text {th }}$ August 1810' (Lithograph by Longman, Hurst, Rees \& Brown, 16 October 1811), aquatint $43 \times 58 \mathrm{~cm}$. Photo courtesy of the National Maritime Museum, Greenwich, London.

After Rainier's departure in 1805, and his replacement first by Nelson's line captain, RearAdmiral Sir Thomas Troubridge (1760-1807; in post, 1805-1807), and then by Troubridge's deputy, Rear-Admiral Sir Edward Pellew (post-1816, Lord Exmouth, 1757-1833; in post 18041809), the situation in Java became a strategic priority for Britain. During the three and a half years of Marshal Herman Willem Daendels' administration (1808-1811), when the island was fortified as a French military base in the Indian Ocean, Britain's position in India and its control of her maritime trade routes to China via the Melaka Straits began to come under threat. It was for this reason that the Governor-General of Bengal, Lord Minto (in office, 1807-1813), was instructed in 1809 by the British Government and the British East India Company (EIC) Directors to eject the French from all their posts and fortified strongpoints in the Indian Ocean, including Réunion (Île de Bourbon), Mauritius (Île de France), and Java. These were all captured by British amphibious operationsnamely, a combination of British naval power (Figure 2) and Indian and British army expeditionary troops (Figure 3) -in 1809, 1810, and 1811 respectively.

Once the Franco-Dutch forces had been defeated in Java with the capitulation of Daendels' hapless successor, Lieutenant-General Jan Willem Janssens (in office, May-September 1811), at kali (river) Tuntang between Ungaran and Salatiga on 18 September 1811, the pressure was on Raffles and Minto to start scaling back the British military establishment. This was more than halved in the months following the August-September 1811 Java campaign from around 11,000 at the time of the initial invasion to just 5,000 troops, mostly Sepoy battalions, who were involved in garrison duties in the key towns of the archipelago. Nearly all the British infantry line regiments and specialist troops (engineers, field artillery, etc.) were shipped back to Bengal and Europe in order to reduce the military establishment costs and free up troops for other theatres of war during the final campaigns against Napoleon (Thorn 1815; Carey 1992, 432-33 n.164; Glendinning 2012, 133-34). 


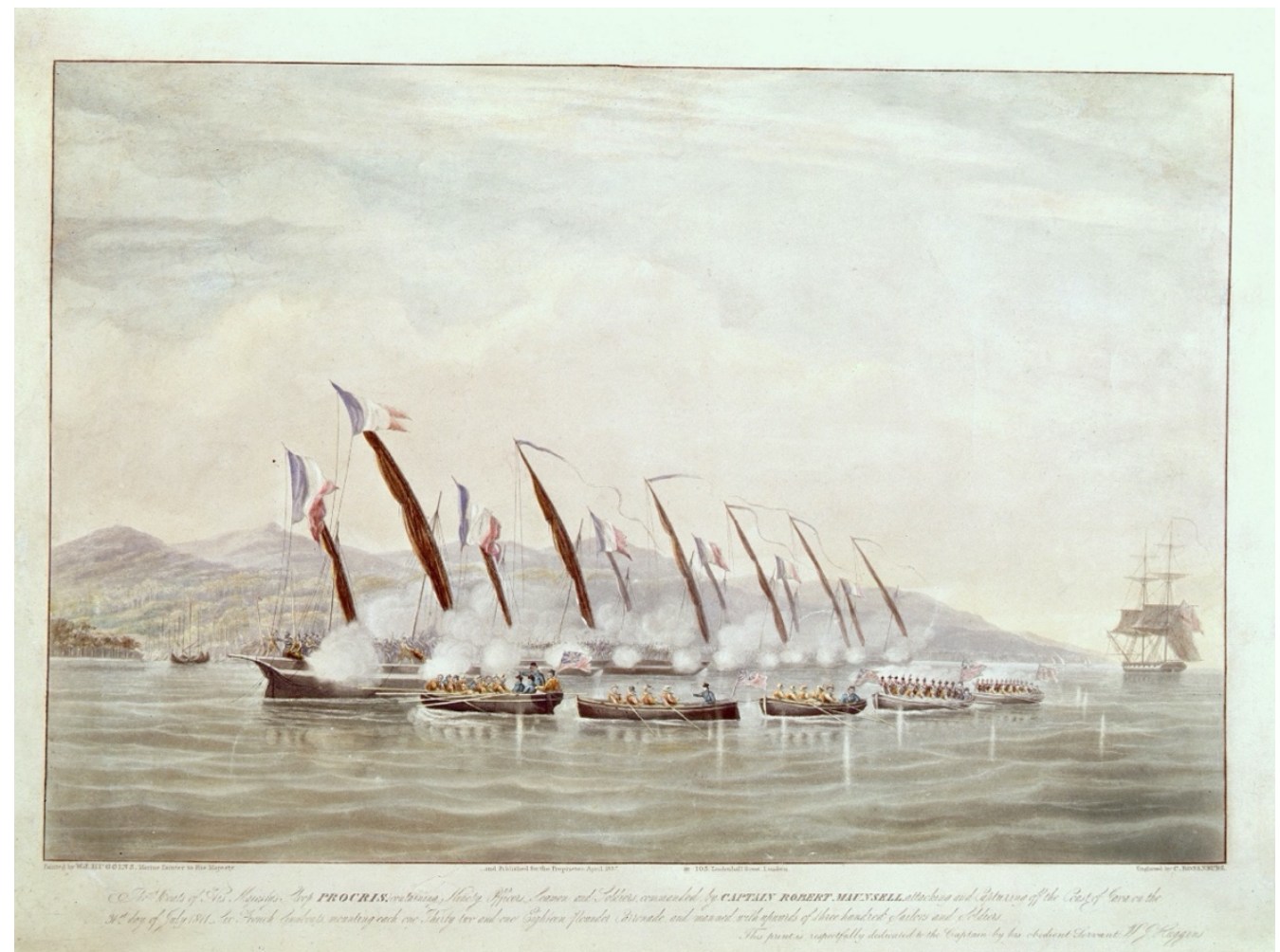

Figure 2. Boats of His Majesty's Sloop Procris (Captain Robert Maunsell) attacking and capturing six French gunboats off the coast of Java at Indramayu on 31 July 1811. Engraving by Charles Rosenberg (flourished mid-19th century) after a painting by the celebrated naval artist, William John Huggins (1781-1845). Oil

on canvas, $71 \times 106.5 \mathrm{~cm}$. Photograph by courtesy of the National Maritime Museum, London.

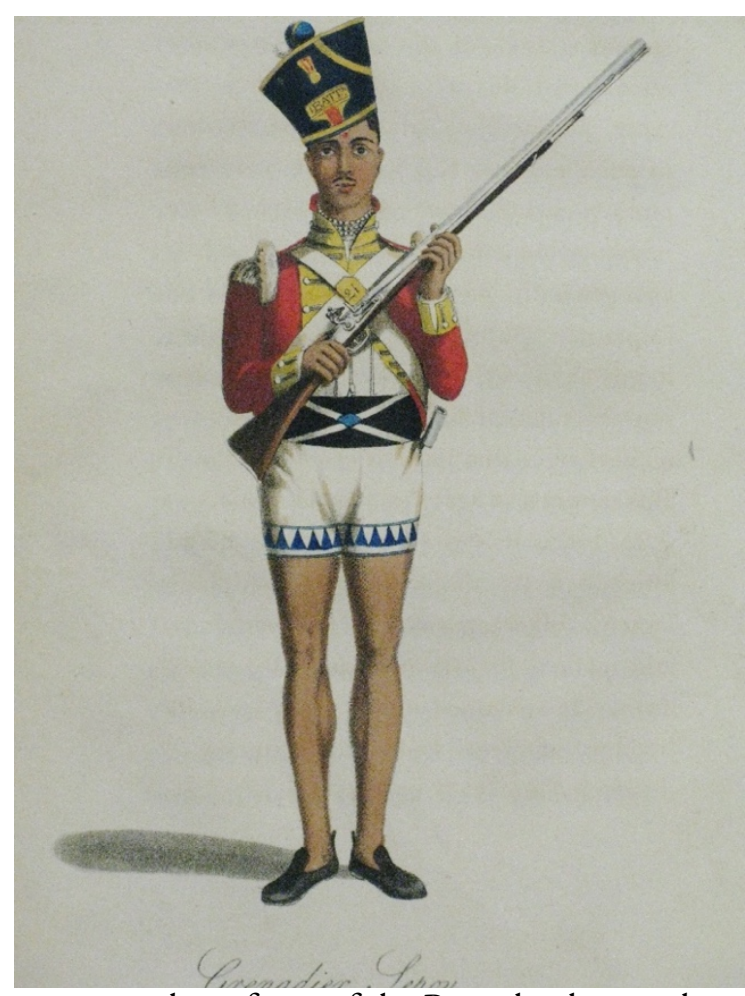

Figure 3. A grenadier sepoy, a member of one of the Bengal volunteer battalions which took part in the British invasion of Java in August-September 1811 and the subsequent attack on Yogyakarta, 20 June 1812. Aquatint by William Daniell (1769-1837) from John Williams, An historical account of the rise and progress of the Bengal native infantry from its first formation in 1757 to 1796 (London: John Murray, 1817), p. 171 facing. 
Given the need for severe economies and the subsequent reduction of the British military establishment on Java in particular, it was important that potential threats from local rulers with substantial military forces at their disposal were eliminated. This led to operations undertaken by Raffles and his army commanders-Colonel (post-January 1812, Major-General) Robert Rollo Gillespie (1766-1814; in post, 1811-1813), Major-General Sir Miles Nightingall (1768-1829; in post, 1813-1815) and Colonel Nathaniel Burslem (c. 1770-1856; in post, 1815-1816)_against local rulers outside Java such as the Sultan of Palembang (March 1812), the raja of Bali Buleleng (May 1814) and the Sultan of Boné (June 1814). But the most important military establishment independent of the colonial government lay in south-central Java. This belonged to the Sultanate of Yogyakarta. Writing in early 1812 after his first bruising encounter with the Second Sultan on 23 December 1811, when he had come within an ace of being killed, Raffles reckoned that the Yogya ruler was 'the main power in the eastern outlying districts', and, if the European power was withdrawn, the Surakarta ruler-Pakubuwono IV (r. 1788-1820)—would be unable to maintain his authority and the sultan's power 'would [then] at once extend over the whole of the eastern districts of Java including the sea coasts' (Carey 2008, 159-60).

This threat could only be eliminated if the Second Sultan was removed. This happened following the 20 June 1812 assault on Yogyakarta which Raffles attacked with 1,200 picked troops (mainly British Indian sepoys from the Bengal and Madras Presidencies). Following the successful three-hour operation which took place between five and eight o'clock in the morning, Raffles could announce to his patron, Lord Minto, in Kolkata that "the European power is for the first time paramount in Java. [...] we never till this moment could call ourselves masters of the more valuable provinces in the interior, nay, our possessions on the sea coasts would always have been precarious and, had [our] military force been materially reduced, much eventual danger was to be apprehended" (Carey 2008, 342-43).

Thus there was a dynamic and logic to British military actions during their five-year occupation of Java at the end of the Napoleonic Wars. It was not just a question of a show of force on the part of the colonial government designed to inspire shock and awe. Instead, the Sultan was targetted precisely because he represented a threat to the very existence of the colonial power in Java since his military assets, if used offensively, could jeopardise the British position on the north coast of Java. At the same time, the plundering of the Yogyakarta court also had a logic to it in that this was one of the ways in which British Indian Sepoy troops were rewarded for battlefield operations. In India, booty was one of the major perquisites of East India Company officers ['loot' is derived from the Hindi word 'lut', meaning 'spoil, booty, or plunder'] and the British army there had fought for the right to keep everything in fortresses, courts and strong points taken by assault (Carey 2008, 466).

\section{Some Strategic Implications of the British Naval Presence in Indonesian Waters, 1808-1833}

\section{Bandung and the postweg (1809-1810)}

When Marshal Herman Willem Daendels arrived in Java on 6 January 1808, he found the island under siege. So rigorous was the Royal Navy's blockade of Java's north coast ports that nothing could move along the north coast without attracting the guns of Rear-Admiral Sir Edward Pellew's Indian Ocean squadron. But Daendels thought big. If a coastal highway was strategically impossible, he would use gunpowder to blast a new mountain road through the Priangan Highlands via Puncak (Megamendung, Figure 4). This led to the foundation on 25 September 1810 of an entirely new regional capital-Bandung - when Daendels ordered the removal of the seat of the local government (kabupaten) from Dayeuh Kolot to the eastern bank of the kali (river) Cikapundung (Katam and Abadi 2006, 2). 


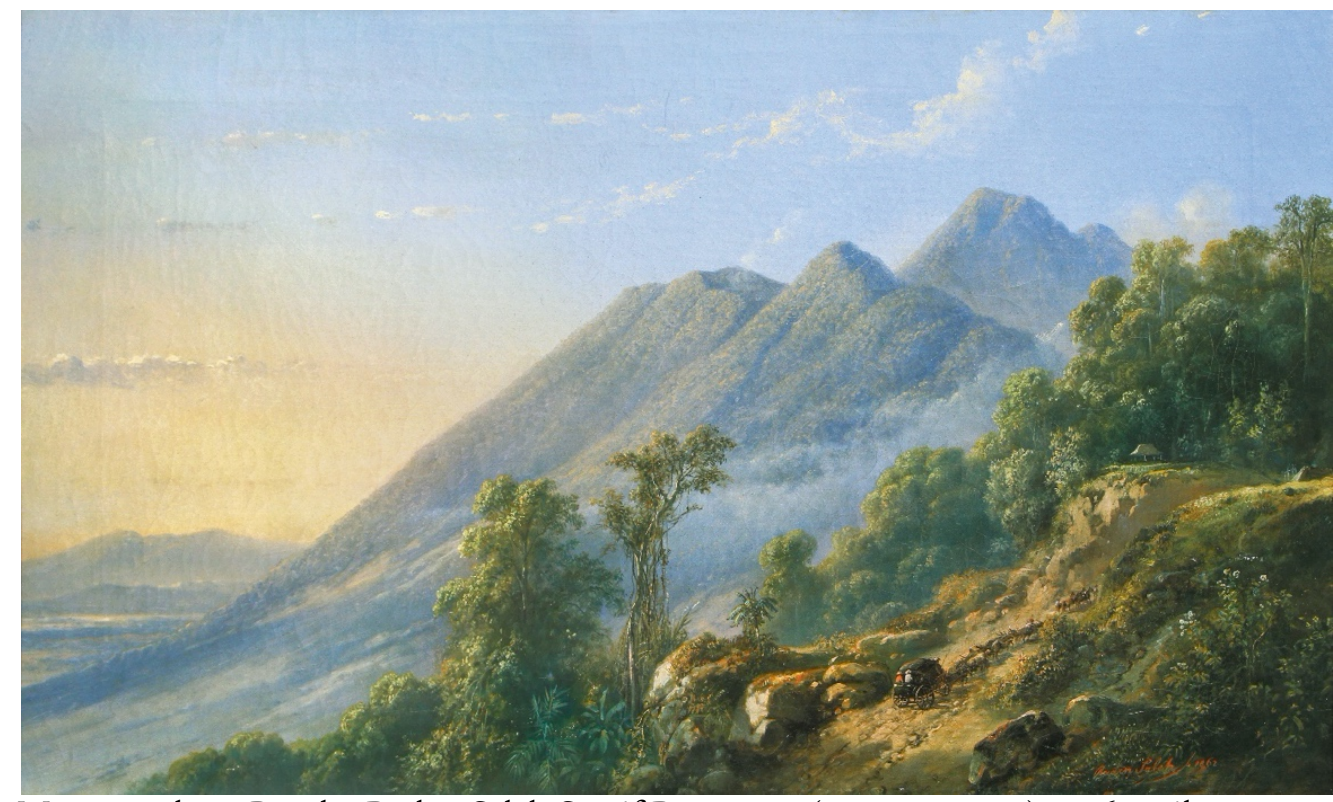

Figure 4. Megamendung Pass by Raden Saleh Syarif Bustaman (c. 1811-1880), 1862, oil on canvas, 90 x 53 $\mathrm{cm}$. Private Collection Indonesia.

Daendels's great trans-Java post road (postweg) was built (1809-1810): "no governor had thought of it before him, and I believe none will dare to contemplate it afterwards" ("aucun gouverneur n'y avoit pensé avant lui et je crois qu'aucun n'auroit osé penser après") was the Belgian officer, Major Éduard Errembault de Dudzeele's (1789-1830), pithy summation of the project's sheer scale when he travelled the road during the Java War (1825-1830) (Carey 2021, 36 n. 10).

Daendels's governorship was not just about roads. It also laid the foundation for the administrative centralization of the Netherlands Indies and post-1945 Indonesia, thus changing forever the relationship between the colonial government in Batavia and the Javanese. Tasked by King Louis of Holland (r. 1806-1810) with sweeping powers to reform the corrupt administration of the former Dutch East India Company (VOC) (9 February 1807) and elevated to the highest military rank as Marshal of Holland (Maarschalk van Holland) (28 January 1807), to ensure Java's defence against the British, Daendels's 41-month tenure as colonial viceroy left a lasting legacy. He was not in the business of reforming a few archaic practices, a little tinkering at the edges to bring the old Dutch East India Company into the modern world. He wanted root-and-branch change. His administration transformed the political and social world of Java. In everything that touched the relationship between south-central Javanese courts-Yogyakarta and Surakarta-and Batavia, from the political demands of the colonial administration, to access to labour and economic resources, to new notions of status, and military and defence requirements in an era of global conflict, it was clear that Java had entered a new age. Like a depth charge, the impact of Daendels's presence would be felt long after his mid-May 1811 departure.

Although based on shaky military foundations, the marshal's administration drew a line under the previous Company (VOC) era. The existence of his new military road — the postweg-marked the beginning of an integrated modern Java whose transport system. This ran west-east by land along the north coast rather than, as previously, north-south following the major rivers connecting the coast and the interior. Nas and Pratiwo $(2002,721)$ have reminded us that 'traditional Javanese life is expressed in its urban form by its orientation towards the mountain and the river'. Once the postweg was constructed, however, it replaced the rivers as the main economic artery. Cosmological notions changed drastically:

"The Chinese did not build their new temples at the riverside anymore, but on the postweg. They perceived the postweg as the new 'breath of life'. The [modern] temple in Lasem built in the twentieth century was not oriented towards the Lasem River, as was the case with the old temple, but faced the grote postweg. A similar change occurred with the 'palaces' [sic, 
dalem $=$ residences] of the regents built [along the posting road] in the mid-nineteenth century." (Nas and Pratiwo 2002, 722)

Over time the grote postweg became one prolonged urbanized area. Java along with the 400kilometre arc of the Kantō plain between Osaka and Tokyo in Japan, developed into one of the most densely populated regions in the world. In Nas and Pratiwo's words, 'one could call Java the longest city in the world with the grote postweg as its main transport and economic artery' (Nas and Pratiwo 2002,721 ). While what remains today of the postweg is almost obliterated by Java's urban sprawl, it did not start out that way. In fact, the use of the new trans-Java highway was heavily restricted at least until 1857 . Only then was it opened to general traffic. Not only was it a military road, but it was also a posting road built for the fast delivery of government dispatches and European personnel. Anyone using it needed official permission (Kraus and Vogelsang 2012, 98). Indeed, the road was not accessible to Javanese vehicles which had to use special carting roads that ran alongside the postweg. Until 1857, it was only for Dutch carriages equipped with the requisite coachmen and footmen. In Kraus's words, "when a colonial officer travelled along this road in an official capacity, it was more than just a journey it was a demonstration of colonial power" (Kraus and Vogelsang 2012, 69). Such impressions were also evidenced in Major Errembault's Java War diary and by non-Dutch witnesses writing in the mid-nineteenth century (Carey 2021, 41).

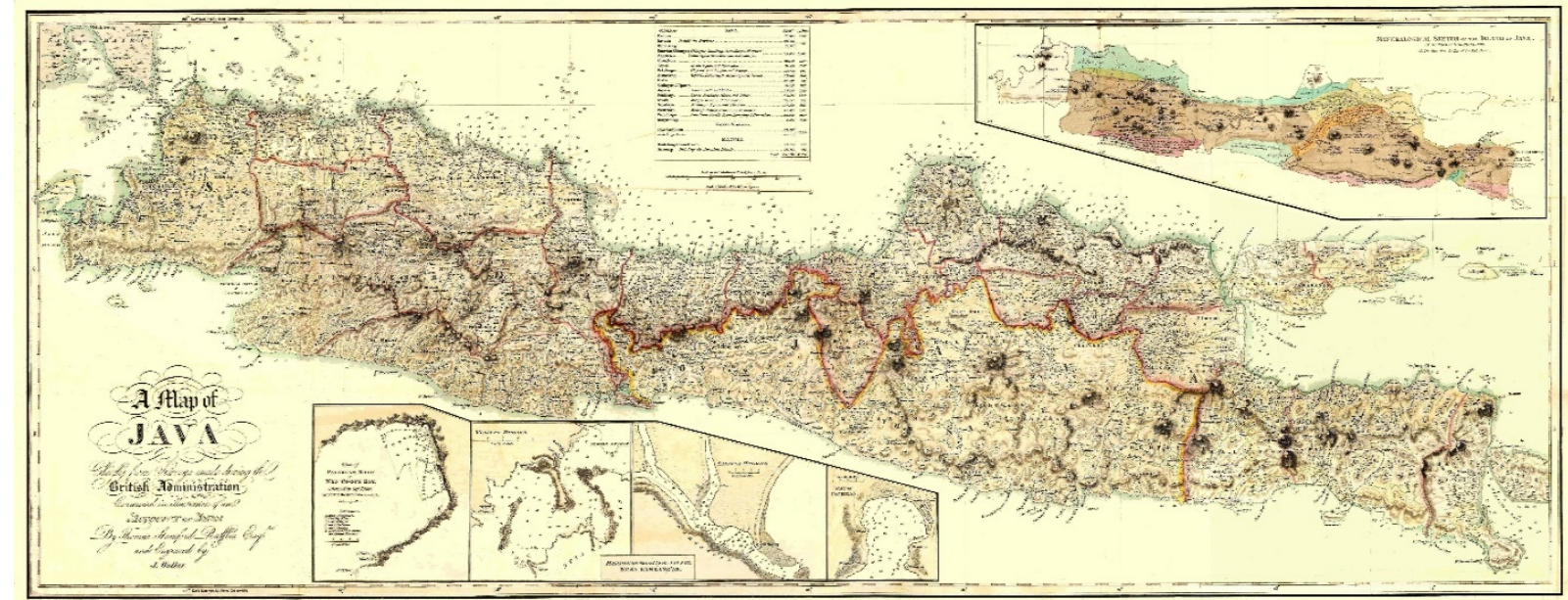

Figure 5.John Walker's (1759-1830) map of Java published in Raffles History of Java (1817). The most detailed every produced up to that point in time, it showed all the mineral and natural resources of Java as well as landing places on the south coast—in particular Pelabuhan Ratu (Wijnkoops Bay), Cilacap and Pacitan — where amphibious forces could be disembarked in the event that the British had to reconquer Java from the Dutch following the end of the Napoleonic Wars in 1815.

Before Raffles departed from Java on 30 March 1816 at the end of his five-year period as Lieutenant-Governor, he oversaw the collection of detailed data on the natural resources of Java and its topography. This was for strategic as much as for scholarly purposes. The modern colonial project put a high value on the accumulation of knowledge and data on colonised territories. Knowledge was power. It facilitated the business of government and also highlighted the natural resources which could be exploited in the event that Java had been retained as a Crown Colony by the British as Raffles hoped. In the case of the exceptionally detailed map compiled for Raffles by the British cartographer, John Walker, there is important additional topographical information with inset maps the major anchorages and bays with depth soundings marked, and even a mineralogical sketch of the island compiled in 1812 by Thomas Horsfield (1773-1859), the American naturalist and friend of Raffles. Disappointed that Java had not been made a Crown Colony and retained as a British possession after the end of the Napoleonic Wars (1799-1815), Raffles determined that he should compile the requisite information to enable a subsequent British invasion of Java from the south coast in the event that this became necessary because of a confrontation with the Netherlands in Europe. This, in fact, 
occurred just four years after Raffles' death (5 July 1826) when the Southern Netherlands rose in revolt against the Dutch (25 August 1830-12 August 1831) and received the support of the great powers of Europe (Great Britain, Russia, France and Prussia) to establish itself as an independent country-Belgium - with its own monarch, Leopold of Saxe-Coburg (1790-1865), who reigned as Leopold I of the Belgians (1831-1865). We will see in the next section how these hostilities over Belgian independence impacted the fate of the recently exiled Prince Diponegoro (1785-1855) and his family in distant Manado (1830-1833).

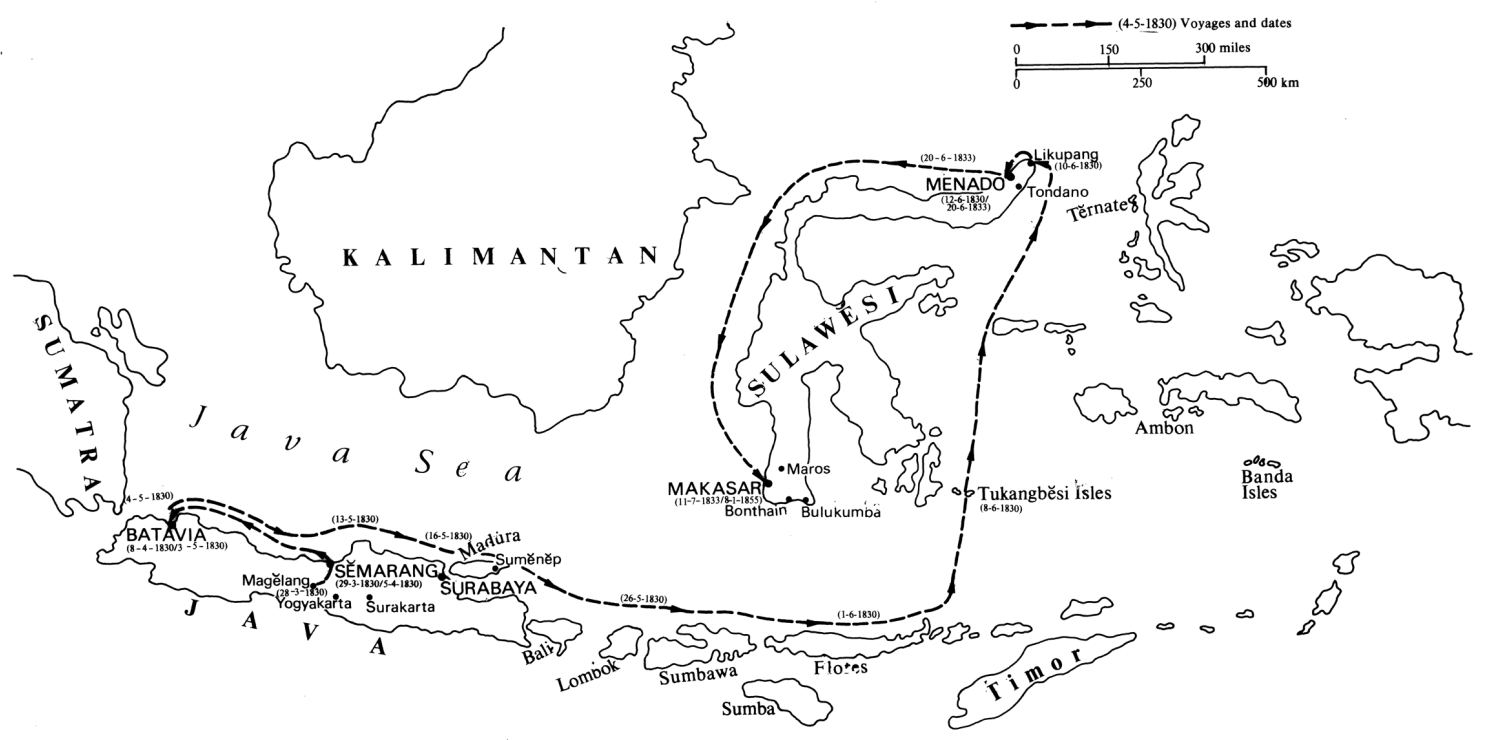

Figure 6. Diponegoro's journey into exile in Manado (1830-1833) on the corvette Pollux (4-5-1830-12-61830) and his subsequent voyage to Makassar (1833-1855) on the sailing sloop Circe (20-6-1833-11-71833). Map drawn by J. Wilbur Wright of Oxford.

The events which took place in Europe had a direct impact on the conditions under which Diponegoro and his family were held in exile in Sulawesi (Celebes). This was because of the Dutch feared that the British would use their naval power and overrun Dutch possessions in the Outer Islands as they had done in the late 1790s and late 1800s (Figure 1).

Although Belgian independence had been proclaimed (4 October 1830), and Leopold of SaxeCoburg elevated as the new Belgian monarch (21 July 1831, r. 1831-1865), the Dutch king, Willem I (r. 1813-1840), had refused to disarm (he later abdicated as Dutch monarch shortly after Dutch recognition of Belgian independence at the Treaty of London on 19 April 1839). A series of military engagements had ensued which eventually led to a French army entering Belgium in support of the Belgian nationalist forces and bombarding the citadel of Antwerp where a Dutch garrison under General David Hendrik Chassé (1765-1849) eventually surrendered after a heroic two-year siege (December 1832). In early 1833, it seemed that the French might even cross the Dutch-Belgian border into Zeeland. With a European war looming, Johannes van den Bosch (in office as Governor [post-1832 Commissioner]-General, 1830-1834) became seriously alarmed that 'an unscrupulous enemy' - by which he clearly meant the British-might seek to use the large numbers of political exiles in the 'outer possessions' for political purposes. In particular, he was concerned that Diponegoro might take advantage of the opportunity of a new European conflict to escape and return to Java to lead a new rebellion (Carey 2008, 735). It was clearly inappropriate for him to remain in the town of Manado close to the shipping routes where British naval forces might reappear at any moment to repeat their previous 1795-1797 and 1808-1810 amphibious operations when nearly all the Dutch outer island possessions had fallen into their hands.

The former Resident of Manado, Daniel François Willem Pietermaat (1790-1848; in office, 1827-1831) was delegated to leave his post at the High Court in Batavia and return immediately to 
Manado to arrange for Diponegoro's transfer to a newly constructed strongpoint deep in the Minahasan interior. Once in Manado, however, Pietermaat soon realised that Van den Bosch's proposals were impractical. The Dutch East Indies Government had no legal sovereignty in Minahasa. Its authority depended on a contract with the local chiefs dating back to 1810 , but this gave them no rights over land. Without the permission of the local authorities no fort could be built in the interior. Besides, none of the chiefs, in Pietermaat's view, would believe that such a strongpoint was being constructed only to house an 'unimportant person' like Diponegoro. They would suspect that it was a move by the government in the direction of outright annexation and they would resist it. If it came to war, what could a garrison of forty Dutch and native troops in Manado do against a hostile Minahasan population of 80,000? Furthermore, the British were well liked in Minahasa: during the period of their rule (1811-1817), they had treated the population well giving lavish presents to the local chiefs and demanding no forced deliveries or personal labour services from the peasant cultivators. If they landed with a strong force of marines, as they had done when they had taken in Banda in August 1810 (Figure 1), they would be welcomed with open arms. An alternative strategy would have to be found.

One such alternative actively canvassed by Van den Bosch both during his period as commissioner-general (1832-1834) and as minister of the colonies (1834-1839), was to send Diponegoro, along with other prominent Indonesian exiles, back to the Netherlands. His suggestion was that they should be held in one of the royal fortresses which served as state prisons for members of the Dutch elite, such as Loevestein in Gelderland and Woerden in the province of Utrecht. All the costs would be met by the Indies exchequer, meaning, in Diponegoro's case, the Yogyakarta court. If Diponegoro had rejected Tondano with its 69 degree Fahrenheit mean early morning temperature as too cold, no leap of the imagination is necessary to contemplate how many Dutch winters he would have survived in the damp fortresses of the New Dutch 'water line' (Nieuwe Hollandse waterlinie) frontier defence system. It was fortunate for the prince that the Dutch king rejected Van den Bosch's proposal out of hand as politically unacceptable (Carey 2008, 735-6). Indeed, it would not be until the early twentieth century that Indonesian exiles were sent back to the Netherlands and then as incountry detainees rather than as state prisoners incarcerated in royal fortresses.

With his plans to transfer Diponegoro to the Netherlands finding little favour, Van den Bosch hit on an Indies alternative. The prince would be moved south in deepest secrecy to Makassar where he would be held until his dying breath in Admiral Cornelis Janszoon Speelman's (1628-1684) great stronghold of Fort Rotterdam. Instead of Manado's puny 40-strong garrison, the south Sulawesi fortress boasted a complement of 200 soldiers and powerful gun batteries mounted on its five great bastions which covered all the approaches from sea and land. It was altogether a more formidable defensive structure. In this way, Diponegoro and his followers would exchange Fort New Amsterdam for Fort Rotterdam travelling the length of the Dutch eastern Indonesian gulag by naval schooner, a clandestine twenty-one days (20 June-11 July 1833) odyssey (Figure 6) made all the more poignant by the name of the vessel tasked with transporting them, the Circe, styled after the queen goddess in Homer's epic who could transform men into animals.

Van den Bosch went to enormous lengths to ensure that even the local Dutch authorities in Manado were not informed of Diponegoro's true destination. The Acting (post-1834, official) Resident of Manado, Joan Pieter Cornelis Cambier (in office, 1831-1842), was to be told that the prince was bound for Ternate. Meanwhile, the schooner's captain was only to be instructed to hold course for Makassar when he had cleared the roads of Manado. On reaching Makassar on 11 July 1833, the ship's officers were sworn to secrecy and forbidden to enter into any correspondence regarding their voyage. The ship's log was altered and immediately after depositing the prince and his party, it sailed to Ambon making it look as though the Moluccas (Maluku) had been its original destination all along. On arrival in Ambon, the captain was relieved of any obligation to report his movements to the local Dutch authorities in Fort Victoria (Carey 2008, 738). But, even these strict instructions seem to have been of little avail in preventing the schooner's Indonesian sailors from reacting badly to the former Java War leader's presence in their midst. Jan Izaäk van Sevenhoven (in office, 1832-1839), who served as a member of the Raad van Indië (Council of the Indies), would 
later advise that Diponegoro should never again be moved by a Dutch warship given the possibility of mutiny amongst the ship's crew. Any further transfers should be by 'colonial trader', namely by ordinary merchantman (Carey 2008, 739).

\section{The Paradoxes of Protection (1795-1833) and the Establishment of Singapore (1819)}

The saga of Diponegoro's secret transfer from Manado to Makassar in June-July 1833 highlights the paradox of British naval power in Southeast Asia for the Dutch. On the one hand, the presence of the Royal Navy in Indonesian waters was a guarantor of Dutch security from the threat of foreign seaborne invasion. Such threats had occurred as recently as the American Revolutionary War (17751782) when the French Indian Ocean Squadron, commanded by its famous admiral, the Bailli de Suffren (1729-1788; in post, 1782-1784), had caused the VOC Supreme Government (Hoge Regeering) in Batavia to request naval assets from Holland and put the city garrison on high alert. It happened again in 1793-1794 during the early period of the French Revolutionary Wars (17921799) when French warships had sailed into the Bay of Batavia and threatened the VOC dockyards on Pulau Onrust (Carey 2010, 168; Zandvliet 1991, 79-80).

With the formal mandate received from the exiled Stadhouder, Willem V (r. 1751-1806), through his 30 January-8 February 1795 'Kew Letters', the British were quick to establish themselves as the dominant naval power in Indonesian waters, a process which had already begun following their decisive victory over the Dutch in the Fourth Anglo-Dutch War (1780-1784) when British ships had been given free navigation of the archipelago seas (Ken 1978, 51). Incursions by French warships on the scale seen in the 1780s and early 1790s became a thing of the past. But this did not mean that the Dutch could now enjoy all the benefits without any of the inconveniences of relying on the world's then superpower to ensure their maritime security.

The example of the exiled Diponegoro in distant Manado underscored the dangers which might arise if the Dutch fell out with the British over issues of European politics. The Dutch king, Willem I's (r. 1813-1840), refusal to accept the fact of Belgian independence put the Netherlands directly athwart British foreign policy. It also meant that if the British or post-1945, the Americans, whose Honolulu-based Seventh Fleet had replaced the Royal Navy's Singapore-China Station squadron as the guarantor of the maritime security of the Dutch East Indies/Indonesia in the aftermath of World War II, there was very little that the Dutch, or post-1949, the newly independent Indonesian government could do about it. During the Java War (1825-1830) and again before the onset of the Aceh War (1873-1904), it was strongly suspected that the British and Chinese merchants operating out of Penang and Singapore were providing weapons to Holland's local Indonesian opponents in south-central Java and Banda Aceh. But, because the British dominated the sea lanes through the archipelago, the Dutch could not mount an effective seaborne operation to prevent the smuggling trade in arms and munitions to Diponegoro's forces.

During Raffles' five-year incumbency as Lieutenant-Governor of Java (1811-1816), it is evident that he was aware of the strategic importance of the two key straits which bisected the archipelago, namely the Straits of Melaka and the Straits of Sunda. Indeed, following the fall of Daendels' great redoubt at Meester Cornelis (Jatinegara) on 26 August 1811, he reported to Minto that stone from Daendels' fortress was being shipped off to build the new defences at Muntok (present-day Mentok) on the island of Bangka. This guarded the sea approaches to Palembang along the Musi River as well as the strategic Bangka Straits and adjacent tin mines on Bangka and Belitung (Carey 2008, 345). Belitung, in particular, was deemed so strategically important to Raffles that he persuaded London via Minto to lay formal claim to it in 1812 and retain it as a British possession after the return of Java to the Dutch on 19 August 1816. It was only given back to the Netherlands in 1824 under the terms of the 17 March Treaty of London which made a formal division of Dutch and Netherlands possessions in the archipelago, with the British exchanging Bengkulu (Bencoolen) for Melaka and British rights over Singapore (1819) being recognised (Heidhues 1991, 2).

Singapore may have been strategically well situated but it had its own navigational challenges as Leonard Andaya has recently pointed out that the seas to the south of Singapore were noted for their coral-fringed islands, and their treacherous winds and currents, not to speak of piracies by the 
local inhabitants [Orang Laut] (Andaya 2021). This remained a navigational challenge until well into the nineteenth century when 'piracy' was suppressed by British naval gunboats and Admiralty hydrographers began charting these waters in a systematic way and accurate Admiralty charts became available. Singapore had been among the most important of the Orang Laut (seafaring ethnic groups) bases because of its strategic position in the international east-west maritime trade route and they remained important until well into the subsequent British period. In Andaya's words, it was not until officials of the British East India Company decided to transform Singapore into an important node in its seaborne empire as a rival to the Dutch in Batavia in the early decades of the nineteenth century that Singapore gradually became transformed into a prominent port city and eventually a global citystate serving not only the negara selat but also the seven seas far beyond SE Asia (Andaya 2021).

The small settlement founded by Raffles in 1819 and declared a free port in 1822, grew rapidly. Strategically placed to eclipse Batavia as a major entrepot servicing the India-China trade, by 1825 just six years after its foundation and a year after it had become a Crown Colony, its population had passed 10,000 and the volume of trade was worth 22 million Spanish dollars (USD 6.400.000 in present-day [2020] money). This was nearly three times that of Penang (8.5 million Spanish dollars) founded forty years previously (1785). Given these statistics, it is no surprise that when the Straits Settlements colony, which initially comprised Penang, Melaka and Singapore (the coaling station of Labuan in Borneo was added in 1846) was founded in 1826. Singapore soon took over the mantle of Penang as the colony's capital (1832). By this time, the volume of trade passing through its port had reached nearly 30 million Spanish dollars (USD 8.500.000 in present-day [2020] money) (Ken 1978, 53).

Singapore was now regarded as a possible point d'appui where British merchants might load tea from China brought down by Chinese junks in exchange for opium and British manufactures, and become a possible port of retreat should the Chinese make it impossible to trade in Canton (Ken 1978, 53). Although Singapore's development as a major naval base servicing the China Station fleet was still nearly a century distant (1921-1941), by the third decade of the nineteenth century British naval dominance of the archipelago seas was absolute. By this time, Batavia, once seen in the seventeenth century as the 'Manhattan' of the east, had been totally eclipsed.

\section{Twentieth-Century Developments}

During the first half of the $20^{\text {th }}$ century, the Indonesian/Indies archipelago again felt the decisive influence of the British Navy on its political situation. This period saw three stages of politicaleconomic change which determined the fate not just of the archipelago but the entire world-namely, the First World War (1914-1918), the interwar crisis (1918-1939), and the Second World War (1939-1945). The Dutch East Indies was affected by all three of these at various levels of intensity.

The First World War did not present an immediate danger of war to the Indies. Since the Netherlands experienced the bitter loss of its southern region-Belgium-in the Belgian Revolutionary War (1830-31), the kingdom and its empire had distanced itself from the European political arena by pursuing a neutral foreign policy whose guiding principle was 'aloofness' (Bussemaker 2000, 115). For more than a century from the Dutch return in August 1816 until the end of the First World War (1918), this principle succeeded in protecting the country and its colonies from the devastation of war. However, this did not mean that the Dutch East Indies was completely spared collateral effects of the First World War. Throughout the war, there were blockades, espionage, and naval battles between the Allied and Axis powers. These hostilities caused major communication disruptions and hampered sea transportation to and from Europe.

The Netherlands was no exception here. Communication between the colonial government in Batavia and the mother country could not be done by electronic communication because such telegrams were often garbled. Therefore, the only way of communication was through typed correspondence which could often take months. In facilitating this relationship between the Netherlands and its vast Asian colony, the British Navy also played a significant role. The Netherlands and its colonies were dependent on the sea routes patrolled by the Royal Navy which alone had the 
capacity to repel or blockade the German naval assets and land forces. Furthermore, Britain also frequently restricted neutral shipping between the Indies and Europe in order to abort the so-called 'Indo-German plan' which had assigned the Dutch East Indies a key role in the overthrow of British power in the Far East (Dijk 2007, xi). In practice, the Indies were left to its own policymaking devices in cases that required speedy resolution.

The success of its foreign policy of neutrality and 'aloofness' during the First World War has made the Netherlands optimistic about maintaining this principle as tensions escalated in the run-up to the Second World War. This was the case both with Germany versus the Netherlands in Europe and Japan against the Dutch East Indies in Asia (Foray 2007, 51). For the colonial government in Batavia, this principle meant that it was not necessary to prepare for military attacks from foreign powers. This confidence was reinforced by the results of the Washington Naval Conference (WNC) in 12 November 1921-6 February 1922, which was signed by four victorious powers with major naval forces in the aftermath of World War I-namely, the United States, Great Britain, France, and Japan. This guaranteed the territorial integrity of the possessions of each signatory. Similar recognition was given by each country to the Dutch in the post-conference memorandum of 6 February 1922 (Bussemaker 2000, 115). However, this provision would only truly secure the possessions of the Dutch empire if the four great powers remained loyal allies.

However, the outcome of the Washington Conference was not what the Western signatories had hoped. Japan was completely dissatisfied with the 1921 provisions of the Conference and even more dissatisfied with a similar meeting in London in 1930 (London Naval Treaty I) at which the Japanese Navy was limited to only two-thirds of the equivalent navies of the US and Britain (Kurasawa 2016, 2). At this point, Japan's alliance with the Allied countries began to crumble. Indeed, it soon became clear that Japan had its own plans for the Dutch East Indies.

Since the 1930s, the danger of an attack coming from Japan had begun to be recognised by the Dutch and caused particular concern in Batavia. Given the lack of military preparation in the Indies, the only safeguard for the continuing security of the archipelago was the defence screen provided by the still powerful British Navy operating from its Singapore, Ceylon (Trincomalee), and Indian naval bases (Bombay Naval Dockyard and Kidderpore docks, Kolkata). Reflecting on this, an Anglo-Dutch military alliance and cooperation in Asia would seem to be a natural outcome. After all, both countries had lucrative Southeast Asian colonies and there was an interest in protecting them from Japanese attack (Bussemaker 2000, 117). However, both the Dutch cabinet in Europe and the Dutch East Indies colonial government still adhered to the principle of neutrality-hoping against hope that Japan would not intervene militarily in the Indies. But, given Japan's invasion of Manchuria in 1931 and ever-increasing tensions between the US and Japan, this was a forlorn hope. Moreover, the US was Japan's most important source of oil and bunkering fuel for the Japanese navy. This meant that Dutch hopes that Japan would spare the Indies from attack was more like whistling in the dark than a serious foreign policy option (Ong Hok Ham 1987, 11-12). In particular, Japanese industry was heavily dependent on imported oil supplies from the US and the Middle East. The conflict with the US would force Japan to seek new sources of oil - to Central Asia or the Indies. Thus, the real danger of Japanese invasion could not be avoided unless the Dutch East Indies were willing to meet Japanese war needs, something which was simply not possible given its principle of neutrality.

The only sensible option the Dutch had in Asia was to make an alliance with Britain. This was the choice of Holland's long-serving prime minister, Hendrik Colijn (in office, 1933-1939). In April and May 1936, Colijn had a discussion with the British Minister in The Hague regarding the defence of the Indies. The report of this meeting was later relayed to the British cabinet. However, Dutch neutrality precluded the creation of a formal alliance. At that time, the importance of the Dutch East Indies to British defence arrangements in Southeast Asia and Australasia had been expressed in numerous war cabinet discussions in London. Any successful Japanese landings in Sumatra would clearly spell disaster for the British military base in Singapore. However, Britain did not want to give a guarantee to protect the Dutch East Indies if the Dutch themselves refused to make meaningful investments in the defence of their colony (Bussemaker 2000, 118). The newly attempted construction of the coastal defence of Java starting in 1936 was possibly an attempt, though a half- 
hearted one, to secure the necessary British military guarantees and an earnest of the Dutch willingness to prepare for war in the Indies.

From the 1930s until the very eve of the Pacific War, there were several views within the Dutch government regarding the potential benefits of an Anglo-Dutch alliance in Asia. Prime Minister Colijn, a staunch anglophile, advocated a closer relationship with Britain and showed a willingness to relinquish the principle of neutrality. However, Colijn's optimism that an Anglo-Dutch alliance would guarantee the security of the Dutch East Indies in case of war was not shared by many of his Dutch cabinet colleagues. The Minister of the Colonies, Charles Welter (in office, 1937-1939 and 1939-1941) - who was directly responsible for the colonial administration and was tasked with articulating Dutch colonial policy_-for example, was still in support of neutrality. Such conflicting cabinet opinions placed a heavy burden on the shoulders of the governor-general, who was caught between a rock and a hard place, seeing all too clearly the ever-present danger of Japanese attack at the same time as accepting the mother country's neutral policy. Given this invidious situation, Governor-General Tjarda van Starkenborgh-Stachouwer (in office, 1936-1942) proceeded with great care. He secretly sent his military staff to audit the joint military meetings with the British —at which the US was also present, but usually just as observers (Bussemaker 2000, 121-23). In addition, he also gave approval for several mutual visits by British and Dutch staff officers to military bases in the Indies and in neighbouring British colonies.

Such visits were carried out in deep secrecy to avoid Japan demanding the same reciprocal military inspection rights. Realistically, the Dutch East Indies colonial government had realised the importance of a formal coalition with Britain in dealing with Japan. However, many partiesincluding the minister of the colonies, Welter-still clung to the principle of neutrality. The situation changed completely when Germany invaded and occupied the Netherlands in a lightning five-day campaign (blitzkrieg) (10-15 May 1940). The royal family and the Dutch cabinet fled to London and formed a government-in-exile. This utterly changed situation left the governor-general with the formidable task of maintaining the Dutch empire without support from the mother country. Perhaps because of his acute awareness of the parlous condition of the Royal Netherlands Indies armed forces (Koninklijk Nederlandsch Indisch Leger, KNIL) — which were almost completely unprepared to counter a foreign invasion - the governor-general took care not to provoke the Japanese and made it appear to Tokyo that he was still naively clinging to the principle of neutrality even after the fall of his home country, the Netherlands.

Why did the Dutch attitude toward the Anglo-Dutch alliance seem so ambivalent? First, there was still confidence that Japan would abide by its promise in the Arita Declaration of 16 April 1940, which had stated that it would not attack the Dutch East Indies as long as the colony still maintained its neutrality. Secondly, the colonial government, especially Governor-General Tjarda, still awaited clarification regarding the United States' attitude towards Japan. Thirdly, the Dutch East Indies still felt that it would be protected by the British defence screen in Singapore. Given that the British had a strategic interest in protecting their Bornean territories (Sabah and Sarawak), the main Japanese invasion route in any assault on the Indies, any Japanese plans for an amphibious strike through the South China Sea, appeared to be blocked. Singapore seemed so impregnable-at least to seaborne invasion-with its massive 15-inch coastal-defence batteries that there was general confidence that the British defence screen would never collapse.

Dutch East Indies reliance on British protection was never actually formalised by any agreement or guarantee from the British side until the last days before Pearl Harbour. Although the Indies colonial press in the early 1940s assumed that the lack of military preparation by the Dutch colonial government indicated that the British had guaranteed the safety of the Indies, no such guarantee had been given either orally or in writing before the eve of the Japanese attack on Pearl Harbour (7-8 December 1941). It was then that the joint defence agreement was struck at the eleventh hour on 5 December 1941 (Bussemaker 2000, 135). In fact, the governor-general's support for a policy of neutrality quickly changed following several high-level staff meetings in Singapore attended by senior military officers from the Dutch East Indies, Britain, and the US. These took place between October 1940 and early 1941 and convinced the colonial government in Batavia that Britain would really 
protect the Indies militarily. This emboldened the Dutch colonial authorities to take even stronger steps against Japan. In June 1941, the Japanese trade mission under Kenkichi Yoshizawa (1874-1965) was sent home empty-handed (Mook 1975, 96-100), and the following August, the Dutch East Indies government went a step further and joined the US in its oil embargo against Japan. But this was sheer bravado-when it came to taking practical steps for the defence of the Indies the Dutch colonial government was still woefully unprepared. Still convinced that their non-formal alliance with Britain and the US meant that these two allied powers would ensure their naval defence and close the northern maritime approaches to the archipelago, they comforted themselves with the conceit that the British in Singapore were more than capable of repelling a Japanese attack should it occur.

Unexpectedly, Japan launched its invasion forces not frontally from the sea off Singapore but by amphibious landings in northern Malaya, striking at just after midnight on 8 December 1942 at Kota Bahru in northern Kelantan even before their Pearl Harbour operation had taken place. Two days later Japanese aircraft operating from their forward bases in Southern Indochina, destroyed Admiral Tom Phillips' main naval squadron protecting the landing grounds, Force-Z, sinking both British battleships, the Prince of Wales and Repulse, within hours of each other on 10 December 1941. The Japanese invasion force then took the land route through the Malay Peninsula positioning themselves to attack the British naval base in Singapore from the landward side via amphibious landings across the narrow strait separating Singapore island from Johor on the night of 8/9 February 1942. By this time the island's vital water reservoirs were in Japanese hands. The port city was then attacked at its weakest point - the forested northern coastline (Kurasawa 2016, 14).

This military strategy was out of the box for the British. They had not foreseen it-all Singapore's powerful naval guns pointed seawards and the British did not have the time or resources to prepare their ground defences on Singapore island in depth. The fact that the Japanese forces were led by one of imperial Japan's most skilful field commanders, General Tomoyuki Yamashita (18851946), the 'Tiger of Malaya', sealed their fate. After his lightning 70-day campaign through the jungles of Malaya, Yamashita launched a final ferocious onslaught from the air, sea, and land on Singaporethe "impregnable fortress"-which finally fell on 15 February 1942. With the fall of the Malay Peninsula and Singapore, hopes of defending the Dutch East Indies against the Japanese vanished.

At that point, the Indies were left to their own devises and were found woefully ill-prepared for an attack by a determined foreign foe. The joint Allied naval forces (American-British-DutchAustralian Command, ABDACOM) under Rear Admiral Karel Doorman (1889-1942) tasked with protecting Java from Japanese invasion was destroyed at the Battle of the Java Sea on 27 February 1942. Ten days later, the entire Dutch East Indies armed forces surrendered unconditionally at the Kalijati Capitulation (8 March 1942) in the City of Subang after the emergency capital of the Dutch East Indies, Bandung, had been threatened with being bombed from the air by the Japanese air force (Bijkerk 1988, 303-4). The joint Allied forces ABDACOM then decided to move their defensive line and headquarters to Australia.

\section{Conclusion}

In this whole story, it is evident that Britain and its naval defence played a critical determining role in the continuation of Dutch colonialism in Asia. After the British naval defeats at the hands of the Japanese on 10 December 1941 and the Battle of the Java Sea (27 February 1942) and the fall of the British military base in Singapore on 15 February 1942 the Dutch colonial state could not long survive. Its collapse was sudden and humiliating. But for the Indonesians it indirectly opened the opportunity for the birth of a new Indonesian state as Sutan Sjahrir (1909-66) clearly stated in his September 1945 pamphlet 'our Struggle' (Perdjoeangan Kita) (Sjahrir 1945). However, this kind of reliance on foreign naval power-post-war provided courtesy of the United States with the massive power of its Honolulu-based Seventh Fleet-has continued with its double-sided repercussions to this day. 


\section{References}

Andaya, L. 2021. “The Realm of the Straits ('Negara Selat') before 1819”. In Stephen Murphy (ed.). Raffles Revisited: Essays on Collecting and Colonialism in Java, Singapore and Sumatra. Singapore: Asian Civilizations Museum.

Anon. (signed A.H.P.). 1854. "Journal of an Excursion to the Native Provinces of Java in the Year 1828 During the War with Diponegoro". Journal of the Indian Archipelago and Eastern Asia (Singapore), vol. 9, pp. 80-158.

Babad Dipanagara. 2020. Babad Dipanagara: A Surakarta Court Poet's Account of the Outbreak of the Java War (1825-30). Ed. and trans. Peter Carey. Malaysian Branch of the Royal Asiatic Society Monograph no. 9. $2^{\text {nd }}$ rev. ed. Kuala Lumpur: MBRAS.

Barker, A. 2020. "Declassified intelligence documents shed light on 1999 Timor-Leste independence", 29-08-2020, https://amp.abc.net.au accessed November 1st, 2020.

Bayly, C. A. 1989. Imperial meridian; The British empire and the world, 1780-1830. Harlow: Longman.

Bijkerk, J. C. 1988. Selamat Berpisah, Sampai Berjumpa di saat yang Lebih Baik (Dokumenter Runtuhnya Hindia Belanda). Jakarta: Djambatan.

Bussemaker, Herman Theodore. 2000. "Paradise in Peril: The Netherlands, Great Britain and the Defence of the Netherlands East Indies, 1940-41". Journal of Southeast Asian Studies, 31.1, pp. 115-36.

Carey, P. (ed. and trans). 1992. The British in Java, 1811-1816; A Javanese account. Oxford: Oxford University Press.

Carey, P. 2008. The power of prophecy; Prince Dipanagara and the end of an old order in Java, 1785-1855. Leiden: KITLV Press. [Verhandelingen 249].

Carey, P. 2010. "Revolutionary Europe and the Destruction of Java's Old Order, 18-08-1830", In David Armitage and Sanjay Subrahmanyam (eds.), The Age of Revolutions in Global Context, c. 1760-1840, pp.167-88. Houndmills, Basingstoke: Palgrave-Macmillan.

Carey, P. 2021. "Towards the Great Divide: Race, Sexuality, Violence and Colonialism in the Dutch East Indies, from Daendels (1808-11) to the Java War (1825-30)", In Farish A. Noor and Peter Carey (eds.), Racial Difference and the Colonial Wars of the $19^{\text {th }}$ Century, pp.31-71. Amsterdam: Amsterdam University Press.

Dijk, K. van. 2007. The Netherlands Indies and the Great War, 1914-1918. Leiden: KITLV.

Foray, Jennifer L. 2007. The Kingdom Shall Rise Again: Dutch Resistance, Collaboration, and Imperial Planning in the German-occupied Netherlands. Ann Arbor: Columbia UP.

Glendinning, Victoria. 2012. Raffles and the Golden Opportunity. London: Profile Books.

Heidhues, Mary Somers. 1991. "Company Island: A Note on the History of Belitung". Indonesia 51 (April):1-20.

Javasche Courant. 1828. No.100, 21-08-1828.

Kahin, A. and George McT. Kahin. 1995. Subversion as Foreign Policy: The Secret Eisenhower and Dulles Debacle in Indonesia. New York: The New Press.

Katam, S. and Lulus Abadi. 2006. Album Bandoeng Tempo Doeloe. Bandung: Navpress Indonesia.

Ken, W. L. 1978. "Singapore: Its Growth as an Entrepot Port, 1819-1941". Journal of Southeast Asian Studies 9.1 (March):50-84.

Kraus, W. and Irina Vogelsang. 2012. Raden Saleh, The Beginning of Modern Indonesian Painting. Jakarta: Goethe-Institut Indonesien.

Kurasawa, A. 2016. Masyarakat dan Perang Asia Timur Raya: Sejarah Dengan Foto yang Tak Terceritakan. Depok: Komunitas Bambu.

Mook, H. J. van. 1975. The Netherlands Indies and Japan, Their Relations, 1940-1941. London: AMS.

Nas, Peter J.M., and Pratiwo. 2002. "Java and de groote postweg, la grande route, the great mail road, Jalan Raya Pos". Bijdragen tot de Taal-, Land-en Volkenkunde 158: 707-25.

Ong Hok Ham. 1987. Runtuhnya Hindia Belanda. Jakarta: Gramedia. 
Reid, A.J.S. 1969. The Contest for North Sumatra: Atjeh, the Netherlands and Britain, 1858-1898. Kuala Lumpur: Oxford University Press.

Sjahrir, S. 1945. Perdjoeangan Kita. Djakarta: Pertjetakan Republiek Indonesia.

Thorn, W. 1815. Memoir of the conquest of Java with the subsequent operations of the British forces in the oriental archipelago. London: Egerton.

Tuan, W. Y. and Lee Kam Hing. 2014. "Aceh-Penang Maritime Trade and Chinese Mercantile Networks in the $19^{\text {th }}$ Century". Archipel 87:173-20.

Williams, J. 1817. An historical account of the rise and progress of the Bengal native infantry from its first formation in 1757 to 1796. London: John Murray.

Zandvliet, K. 1991. "Dandels en de nieuwe kaart van Java”, In F. van Aanrooy et al., Herman Willem Daendels 1762-1818. Geldersman-patriot-Jacobijn-generaal-hereboer-maarschalk-Gouverneur, van Hattem naar St George del Mina, pp. 77-105. Utrecht: Matrijs. 